\title{
Introduction to RISC-KIT: Resilience-increasing strategies for coasts
}

\author{
Ap van Dongeren ${ }^{\mathrm{a}, *}$, Paolo Ciavola ${ }^{\mathrm{b}}$, Grit Martinez $^{\mathrm{c}}$, Christophe Viavattene ${ }^{\mathrm{d}}$, Tom Bogaard ${ }^{\mathrm{a}}$, \\ Oscar Ferreira ${ }^{\mathrm{e}}$, Ruth Higgins ${ }^{\mathrm{f}}$, Robert McCall ${ }^{\mathrm{a}}$ \\ a Deltares, Delft, The Netherlands \\ ${ }^{\mathrm{b}}$ Dipartimento di Fisica e Scienze della Terra, Università di Ferrara, Ferrara, Italy \\ ${ }^{\mathrm{c}}$ Ecologic Institute, Berlin, Germany \\ ${ }^{\mathrm{d}}$ Middlesex University, London, UK \\ e CIMA/FCT, University of Algarve, Faro, Portugal \\ ${ }^{\mathrm{f}}$ Eurocean, Lisbon, Portugal
}

\section{A R T I C L E I N F O}

\section{Keywords:}

Coastal hazards

Coastal risk assessment

RISC-KIT

Coastal storms

Disaster risk reduction

Cultural dimension of risk assessment

\begin{abstract}
A B S T R A C T
Recent and historic low-frequency, high-impact events have demonstrated the flood risks faced by exposed coastal areas in Europe and beyond. These coastal zone risks are likely to increase in the future which requires a reevaluation of coastal disaster risk reduction (DRR) strategies and a new mix of PMP (prevention, e.g., dike protection; mitigation, e.g., limiting construction in flood-prone areas and eco-system based solutions; and preparedness, e.g., Early Warning Systems, EWS) measures.

In response to these challenges, the RISC-KIT project has delivered a set of open-source and open-access methods, tools and management approaches to reduce risk and increase resilience to low-frequency, highimpact hydro-meteorological events in the coastal zone (the "RISC-toolKIT"). These products enhance forecasting, prediction and early warning capabilities, improve the assessment of long-term coastal risk and optimise the mix of PMP-measures.

In this paper an introduction is provided to the objectives, products, applications and lessons-learned of the RISC-KIT project, which are the subjects of this Special Issue. Subsequent papers provide details on the tools and their application on 10 case study sites in Europe.
\end{abstract}

\section{Introduction}

Recent and historic storm events have demonstrated large impacts on coastal zones in Europe. Among these events are the 2010 Xynthia storm in France (Kolen et al., 2010; Garnier and Surville, 2010; Lumbroso and Vinet, 2011; Bertin et al., 2012), the 2013 Xavier/St. Nicholas storm in North-West Europe and the 2015 St. Agatha storm in the Adriatic (Perini et al., 2015), as well as historic events such as the 1953 Flood in Northwest Europe (Baxter, 1953; Gerritsen, 2005), the 1962 Floods in Hamburg and the 1872 flood in Kiel Fjord (WSB, 2015), and older events such as the 1775 storm studied by Baart et al. (2011).

Coastal risk as a result of hydro-meteorological events is likely to increase due to two effects: 1 ) because of predicted climate change the hazards of sea level rise and coastal flooding (due to marine storms and fluvial run-off) may increase; and 2) on-going coastal development will increase the impact (or consequences) of these events. Without adaptation, flood damage on European coasts will increase up to 17 billion
Euros per year (IPCC, AR 2015). These issues are not limited to Europe, as $10 \%$ of the world's population (600 million) lives in coastal areas with an elevation lower than $10 \mathrm{~m}$ above sea level (McGranahan et al., 2007). Worldwide, without adaptation, $0.2-4.6 \%$ of the global population is expected to be flooded annually in 2100 under $25-123 \mathrm{~cm}$ of global mean sea-level rise, with expected annual losses of $0.3-9.3 \%$ of the global gross domestic product (Hinkel et al., 2014).

With this view of the future, coastal authorities need to assess the level of impact and the risk in their coastal zones, and implement Disaster Risk Reduction (DRR) measures to prevent or mitigate coastal disasters. To facilitate risk reduction, the UNISDR (2015) formulated the Sendai Framework for Action, and the EU has issued the Floods Directive in 2007. However, both these frameworks are not specific for coastal hazard and impact issues and do not provide appropriate tools to analyse risks. Therefore, methods to identify hotspots of risk and to assess the effectiveness of DRR measures in coastal zones have to be developed to guide effective disaster risk prevention and management. However, in order to

\footnotetext{
* Corresponding author.

E-mail address: ap.vandongeren@deltares.nl (A. van Dongeren).
} 
reach that goal, a number of questions need to be addressed:

- Where on the coast are areas (or "hotspots") of higher risk located? What are the areas that are to be prioritized?

- What was the impact of past storms and what may be the impact of future coastal hazard scenarios?

- What are effective and (socially) acceptable DRR measures at a hotspot?

- How can DRR measures best be implemented, given the available resources?

- What are the socio-cultural and historic aspects of DRR measures? How do they influence risk assessment and management at regional scales?

- Can a generic approach be applied across Europe, in both data-rich and data-poor environments?

The RISC-KIT project has developed methods, tools and approaches to help answer these questions. RISC-KIT was an EU-funded project with 18 partners across Europe and coordinated by Deltares, The Netherlands (Van Dongeren et al., 2014; www.risckit.eu).

The RISC-KIT toolkit, publically available as free-ware or opensource, comprises five tools. In this Special Issue, all tools and examples of their application on 10 case study sites in Europe are presented and discussed. In this way, we hope that potential users will gain insight into the theory behind and the potential applicability of these products on their coasts. In this paper, the components of the toolkit and their application on 10 case study sites in Europe will be introduced and reference will be made to subsequent papers in this special issue. In addition, we discuss the lessons learned from the project with recommendations for further research.

\section{The RISC-KIT toolkit}

\subsection{RISC-KIT tools in the disaster management cycle}

The RISC-KIT toolkit is comprised of five elements, which are the

1) Storm Impact Database

2) Coastal Risk Assessment Framework (CRAF)

3) Web-based Management Guide

4) Hotspot Tool for DRR assessment, Early Warning and Decision Support (EWS/DSS)

5) Multi-criteria Assessment (MCA)

These tools can be plotted on the Disaster Management Cycle (Fig. 1). This cycle describes the stages of action that take place after a disaster has occurred. First, there is the immediate Response such as emergency relief, then follows a phase of Recovery in which the affected area is

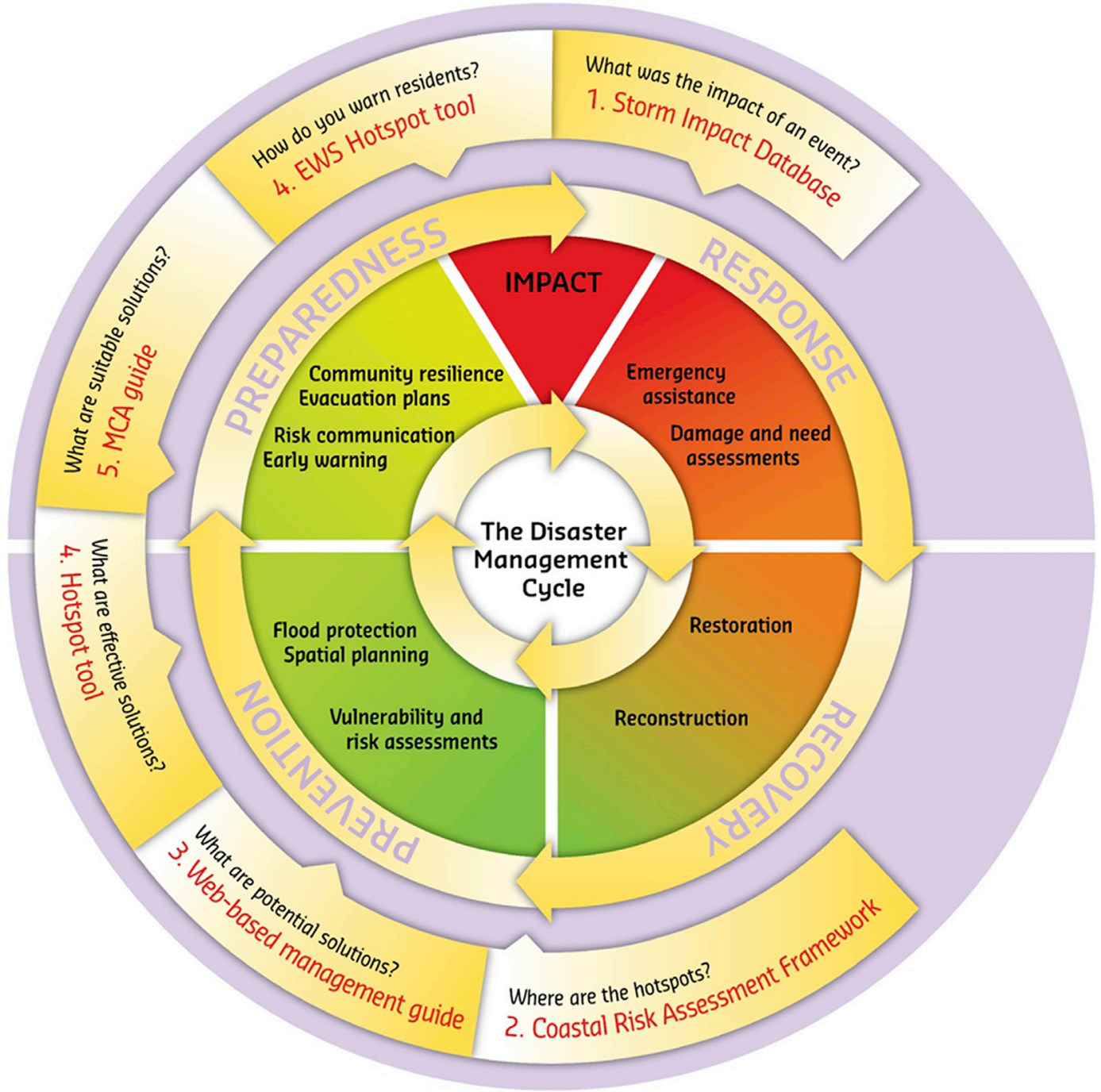

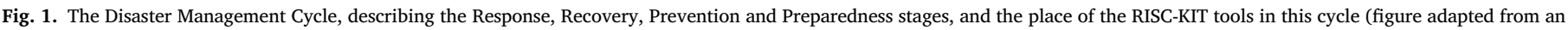
original by and courtesy of C. van de Guchte, Deltares). 
brought back to its original functional state. Then follows a Prevention phase in which risk assessments are made and DRR plans are implemented in order to reduce the impact of a subsequent disaster. With the measures in place, the Preparedness phase awaits a new impending impact. The Storm Impact Database records the impacts of previous disasters and thus comes first. The CRAF, Web-based Management Guide, Hotspot Tool and MCA guide are especially applicable in the prevention and mitigation phase of the cycle, with the Hotspot Tool in Early Warning System mode applicable in the preparedness mode. The tools are described in order of application below.

\subsection{What was the impact? The storm impact database}

If a coastal manager wants to assess risk on a stretch of coast, one of the first acts is to gather data from previous events. These information should concern not only physical data of tides, waves, land use and infrastructure, but also of historic events and impacts. For this purpose, we developed the Storm Impact Database, which contains (meta) data of the impact of historical storms (surges, winds, flash floods) in the case study areas. The tool is described in detail in Ciavola et al. (2017, this issue) with specific attention to the collection and classification of historical events at some of the study areas in Garnier et al. (2017, this issue). The database includes not only physical but also socio-economic, cultural and environmental information. A WEB-GIS interface has been developed to upload impact-oriented event data at each of the RISC-KIT case study sites. Coastal managers and decision makers can subsequently use the event visualisation interface to filter, view and export any relevant information as desired. The database has been built conforming to the guidelines of the INSPIRE directive.

Such a database will strengthen the efforts of local communities and national governments to apply the Floods Directive, raise historical awareness of what has occurred, and lead to an increased understanding of the stakes and vulnerabilities of the case study sites in a long-term perspective. Within the project, the database is a source of validation data to test the effectiveness of DRR scenarios using the hotspot tool (see below). The Storm Impact Database is available through the RISC-KIT project website (www.risckit.eu).

\subsection{Where are the areas of increased risk? The Coastal Risk Assessment Framework (CRAF)}

The Coastal Risk Assessment Framework (CRAF) is designed to answer the question where areas of increased risk (so-called "hotspots") are located on a particular coast. The details of this tool are described in Viavattene et al. (2017, this issue). In summary, the CRAF takes a two-step approach to select the hotspots (Fig. 2).

In the first phase, sectors along the coast with a high potential risk to coastal hazards are determined for different return periods, hazard indicators (e.g., wave overtopping, flooding and shoreline erosion) and exposure indicators (e.g., land use, social, transport, utilities and economic activities) in the form of a coastal index. In the second phase, an analysis is performed on the highest ranking potential hotspots using more advanced hazard and impact assessment models. The hazards are modelled using a 1D process-based, multi-hazard model (XBeach 1D, Roelvink et al., 2009, 2017; this issue) combined with, if necessary, a 2D flooding model such as LISFLOOD (De Roo et al., 2000). The considered hazards are thus erosion, flood depth and discharge (also known as "depth velocity").

The hazards computed in Phase 2 are input into an impact analysis at the regional scale using the INDRA (INtegrated DisRuption Assessment) model, which considers household displacement, household financial recovery, regional business disruption, business financial recovery, ecosystem recovery, risk to life, regional utilities service disruption, and regional transport disruption (Viavattene et al., 2017; this issue).

The hotspots are scored and ranked using a Multi-Criteria Assessment in consultation with stakeholders. The flexibility of the tool allows tailoring of the comparative analysis to different contexts and adaptation to the quality of resources and data available. The Phase 2 analysis yields the identification of the most critical hotspots.

\subsection{What measures are available? The web-based management guide}

Having established where the areas of higher risk are, a coastal manager would like to investigate what measures are available to reduce risk. Therefore, as a third tool, the RISC-KIT project developed a webbased management guide of DRR measures that will help answer the questions of what potential measures are and how they can be implemented in a hotspot. The potential of measures does not only depend on the technical feasibility, but also on social, cultural and historical aspects which need to be evaluated by multiple disciplines. Such interdisciplinary collaboration between the social sciences and humanities and the natural sciences/engineering is a prerequisite in formulating disaster risk reduction measures for coastal regions and is described in Martinez et al. (2017, this issue).

The web-based management guide, which is described in Stelljes et al. (2017, this issue), highlights key principles recommended for the implementation of local DRR measures using examples from the case studies and elsewhere to provide practical illustrations. It is intended to give guidance to coastal managers in Europe and those facing similar challenges beyond the region as well as other groups concerned with coastal management (i.e., coastal resource users, technical and scientific experts, students, and policy makers).

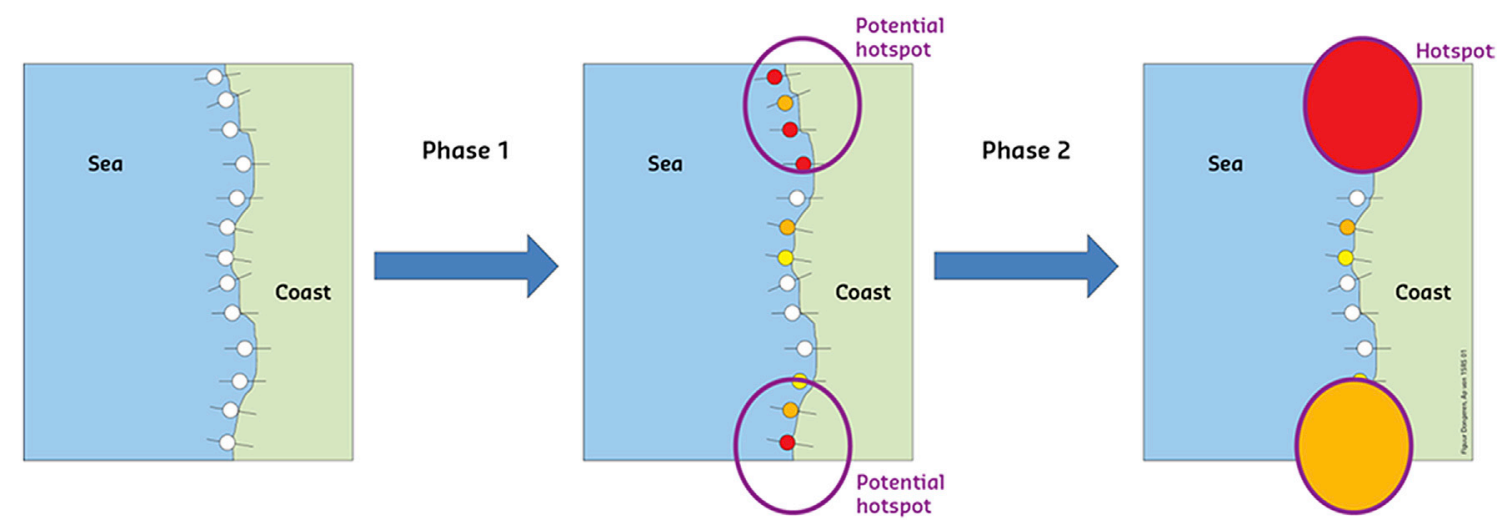

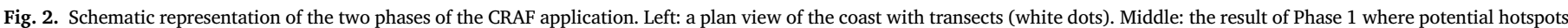

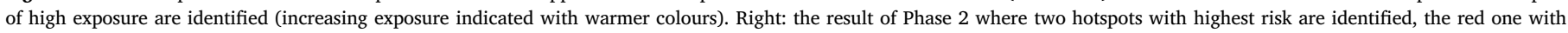
highest risk. (For interpretation of the references to colour in this figure legend, the reader is referred to the web version of this article.) 


\subsection{What is the effectiveness of DRR measures? The hotspot EWS/DSS} tool

The Hotspot (Early Warning System/Decision Support System) tool has been developed to help assess the effectiveness of selected potential DRR measures and to provide residents and authorities with advanced warning of impending hazards. As such, the tool can be used in two modes: as a Decision Support System (DSS) and as an Early Warning System (EWS).

In DSS mode, the Hotspot tool is used to aid decision-making in the Prevention phase by simulating and evaluating the effectiveness of current and potential future DRR measures under storm conditions. This is achieved by the simulation of historical and climate-change related storm scenarios with and without DRR measures in place. From these simulations we obtain predictions of local flooding and erosion, which we combine with characteristics of the local population, built environment and infrastructure, to compute storm impact and the effectiveness of the measures. As effective coastal risk management rarely involves the implementation of a single DRR measure, the (inter)dependencies between measures is considered when assessing the overall contribution to risk reduction. Cumiskey et al. (2017, this issue) present a framework that utilises a pathway-based approach that identifies primary measures that have the potential to directly influence risk reduction at the individual/household level and how these relate to the implementation of those (non-primary) measures that do not directly affect risk reduction.

The results of the hazard and impact simulations are stored in a Bayesian-based Decision Support System (DSS; Jäger et al., 2015, 2017; Poelhekke et al., 2016 this issue) that visualizes the relation between hazards, impacts and DRR measures, and gives an end user insight in how a change in either of these components of risk affect the others.

In EWS mode the Hotspot tool constitutes a Coastal Flood Early Warning System (EWS). As described in Bogaard et al. (2016), we have extended the use of the Delft-FEWS (Flood Early Warning System), originally developed for river flooding application (Werner et al., 2013) to enable real-time surge, wave, coastal erosion, flooding and impact predictions. Rapid EWS predictions of local hazards and impacts at the hotspot, including an estimate of their uncertainty, are provided by coupling of the Bayesian network of the DSS to the forecasts of the large-scale process-based models EWS, thereby eliminating the need to run detailed and computationally-expensive multi-hazard morphodynamic models within the EWS (Fig. 3).

\subsection{What are suitable solutions? The Multi-criteria assessment}

Finally, the selected DRR strategies will be discussed with end users and stakeholders. To this end, we developed a Multi-Criteria Assessment (MCA; Barquet and Cumiskey, 2017, this issue). This tool will enable users from different backgrounds working in high-risk coastal areas to use participatory methods like MCA as tools to integrate various components of a complex project (e.g., qualitative and quantitative data; expert and local knowledge), for gathering data, facilitating interaction, and communicating results. The innovative part of the tool is the adaptation of MCA techniques to diverse contexts and the use of MCA to co-produce knowledge, facilitate local-expert interaction, communicate outputs, and verify results.

\section{Application to case study sites}

The RISC-KIT tools have been applied to 10 case study sites, which are located on each of Europe's regional seas (Fig. 4). The case study sites represent a diverse set of characteristics so that the broad applicability of the tools can be tested. Following Ferreira et al. (2017 this issue), the sites are characterized by:

a) Geomorphic settings: barrier islands of Ria Formosa, salt marshes of North Norfolk, an estuary in La Faute-sur-Mer, a fjord-like inlet at Kiel, a delta plain at Tordera, an armoured coast at Zeebrugge, the open and urbanized beaches of Porto Garibaldi-Bellocchio and Varna, the narrow and relatively sheltered beaches of Kristianstad and the estuary-mouth embayed beaches of Bocca di Magra.

b) Land use: the deep-sea port of Zeebrugge, the port and town in Varna and Kristianstad, the campsites in Tordera Delta, the large touristic occupation at Porto Garibaldi-Bellocchio and at Bocca di Magra, the natural park of Ria Formosa, the small low-lying villages of La Fautesur-Mer and North Norfolk and the marina in Kiel Fjord;

c) Hydro-meteo forcing, with relatively low wave energy in small or enclosed seas (Mediterranean, Adriatic, Baltic and Black Sea) when compared to more exposed coasts (Atlantic and North Sea), different tidal ranges (from micro to macrotidal), influence/absence of fluvial/ estuarine interaction, and high (e.g., Adriatic and North Sea coasts) to low (e.g., Black Sea and South Atlantic coast) influence of storm surges.

d) Hazard type, such as coastal erosion, coastal inundation by surges or waves, overwash and breaching.

e) Socio-economic, cultural and environmental aspects, as for example the port of Zeebrugge (crucial for facilitating trade and bringing

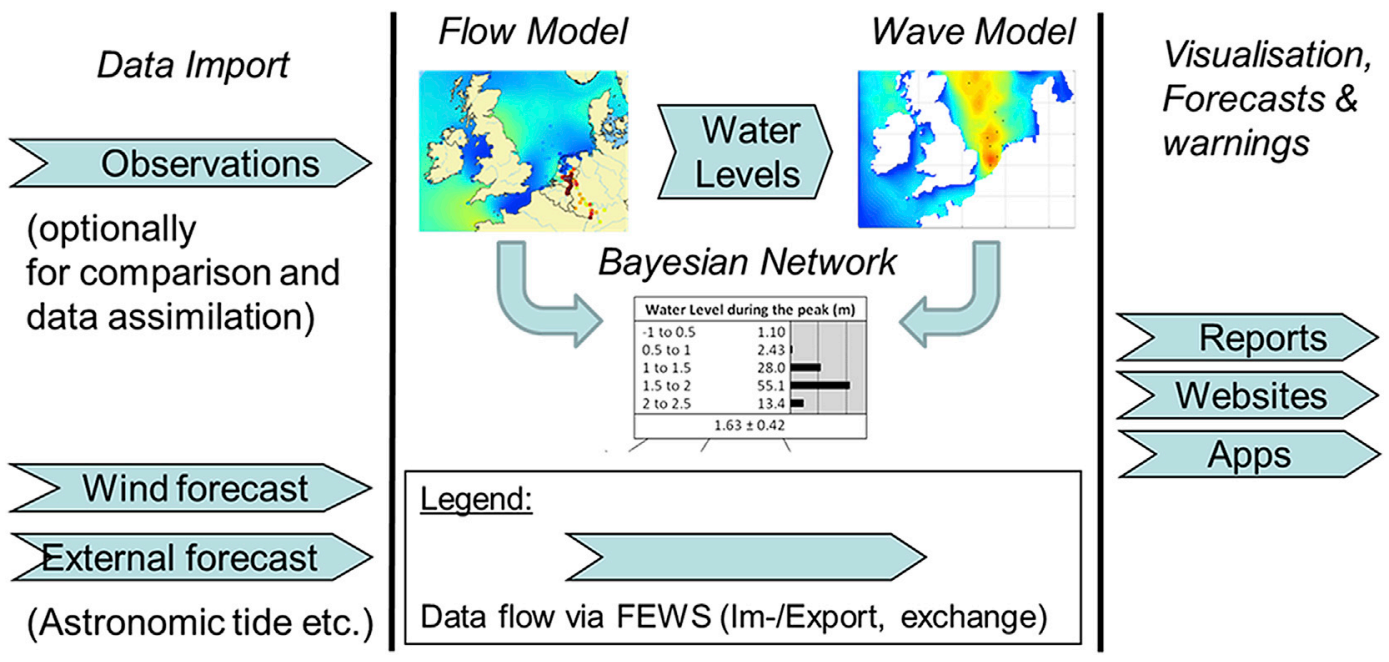

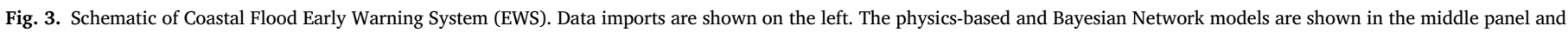
the visualisation and reporting output is shown on the right. 


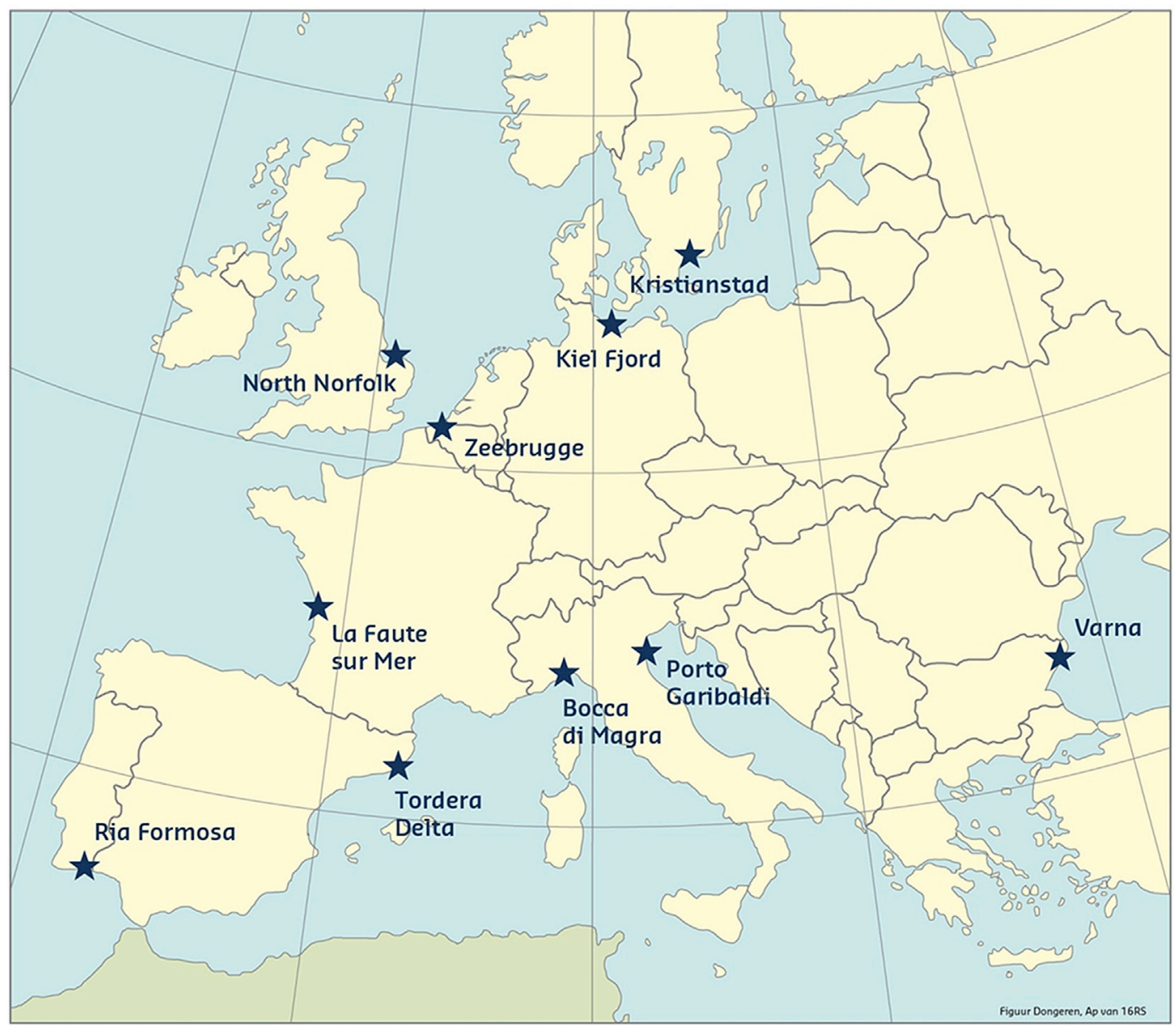

Fig. 4. RISC-KIT case study sites in Europe.

significant economic benefits for the entire Belgium), the North Norfolk Coast Special Area of Conservation (a Special Protection Area under the Ramsar Convention), the touristic areas of Porto GaribaldiBellocchio, Varna, Tordera and Bocca di Magra, the relatively local character of the Wendtorf (Kiel) marina and Praia de Faro occupation (local fisherman and residents), the national relevance of a wellknown alcoholic spirit factory and Port of Ahus exposed at Kristianstad and the unquestionable disruptive effect on the population at La Faute-sur-Mer as proved by Xynthia storm in 2010.

Before the tools were used, case study partners were trained to ensure correct and effective application. The validation was performed by comparing the findings (e.g., identified hotspots, erosion or flooding levels) against historical storms and field records. Depending on their personal background, project partners found this process more or less challenging. However, all partners could apply the tools on their sites, which demonstrates the usability of the tools.

In this issue, the applications of the tools are described in a number of papers outlined in Table 1.

We conclude this special issue with a synthesis of overall findings of the application of the CRAF and hotspot tools (Ferreira et al., 2017 this issue).

\section{Achieved states of the RISC-KIT tools}

Although it was not an explicit goal of the RISC-KIT project to define the Technology Readiness Level (TRL; as within the European Commission's Horizon 2020 Research and Innovation Programme; COM, 2014) for each developed tool, Table 2 indicates the degree of development of
Table 1

RISC-KIT case study sites, the special issue contributions and the highlighted tool.

\begin{tabular}{|c|c|c|c|}
\hline $\begin{array}{l}\text { Case study } \\
\text { site }\end{array}$ & Country & Paper & Tool highlighted \\
\hline Ria Formosa & Portugal & $\begin{array}{l}\text { Plomaritis et al. (2017a, this } \\
\text { issue) } \\
\text { Plomartis et al. (2017b, this } \\
\text { issue) }\end{array}$ & $\begin{array}{l}\text { Hotspot tool } \\
\text { CRAF }\end{array}$ \\
\hline Tordera Delta & Spain & $\begin{array}{l}\text { Jiménez et al. (2017, this } \\
\text { issue) }\end{array}$ & CRAF \\
\hline $\begin{array}{l}\text { Porto } \\
\text { Garibaldi }\end{array}$ & Italy & $\begin{array}{l}\text { Armaroli and Duo (2017, this } \\
\text { issue) }\end{array}$ & CRAF \\
\hline $\begin{array}{l}\text { La Faute sur } \\
\text { Mer }\end{array}$ & France & Huguet et al. (2017, this issue) & Hotspot tool \\
\hline North Norfolk & U.K. & $\begin{array}{l}\text { Christie et al. (2017, this } \\
\text { issue) }\end{array}$ & CRAF \\
\hline Zeebrugge & Belgium & Bolle et al. (2017, this issue) & Hotspot tool \\
\hline Kristianstad & Sweden & $\begin{array}{l}\text { Barquet et al. (2017, this } \\
\text { issue) }\end{array}$ & $\begin{array}{l}\text { CRAF, hotspot tool, } \\
\text { MCA }\end{array}$ \\
\hline Varna & Bulgaria & $\begin{array}{l}\text { Valchev et al. (2017, this } \\
\text { issue) }\end{array}$ & Hotspot tool \\
\hline $\begin{array}{r}\text { Bocca di } \\
\text { Magra }\end{array}$ & Italy & $\begin{array}{l}\text { De Angeli et al. (2017, this } \\
\text { issue) }\end{array}$ & CRAF \\
\hline
\end{tabular}

the tools. This is particularly challenging for tools that integrate physical, engineering, natural, social, economic and cultural aspects as is the case for most of the RISC-KIT tools.

\section{Lessons learned and recommendations for future research}

On the basis of our findings from the development and application of 
Table 2

Technology Readiness Levels of the RISC-KIT tools.

\begin{tabular}{|c|c|}
\hline Tool & TRL \\
\hline $\begin{array}{l}\text { Storm Impact } \\
\text { Database }\end{array}$ & $\begin{array}{l}\text { TRL 6: Technology demonstrated in relevant environment. The } \\
\text { system was developed and already assessed and used by } \\
\text { external users. External users have requested to add their } \\
\text { own data. }\end{array}$ \\
\hline CRAF (Phase 1) & $\begin{array}{l}\text { TRL 7: System prototype demonstration in operational } \\
\text { environment. Phase } 1 \text { of the CRAF was successfully } \\
\text { demonstrated in } 10 \text { different case study locations and has } \\
\text { been applied by partners in other areas as well (Denmark, } \\
\text { Andalusia (Spain), West Africa, Pacific Islands). }\end{array}$ \\
\hline CRAF (Phase 2) & $\begin{array}{l}\text { TRL 6: Technology demonstrated in relevant environment. Phase } \\
2 \text { of the CRAF was successfully demonstrated in } 10 \text { different } \\
\text { case study locations, demonstrating the tool's value for } \\
\text { coastal management. Compared to CRAF Phase } 1 \text { however, } \\
\text { Phase } 2 \text { has not yet been implemented in other pilot projects } \\
\text { and is not yet at the development level to be applied } \\
\text { operationally. }\end{array}$ \\
\hline Web-based & TRL 8: System complete and qualified. The Web-based \\
\hline $\begin{array}{l}\text { Management } \\
\text { Guide }\end{array}$ & $\begin{array}{l}\text { Management Guide is fully developed and operational. It was } \\
\text { also validated by case study owners and end-users. }\end{array}$ \\
\hline $\begin{array}{l}\text { Hotspot (EWS/DSS) } \\
\text { tool }\end{array}$ & $\begin{array}{l}\text { TRL 6: Technology demonstrated in relevant environment. The } \\
\text { Hotspot Tool was successfully demonstrated at } 10 \text { different } \\
\text { environments within the project. }\end{array}$ \\
\hline MCA & $\begin{array}{l}\text { TRL 6: Technology demonstrated in relevant environment. The } \\
\text { MCA is fully developed and ready to be applied. It was also } \\
\text { validated by case study owners and end-users. }\end{array}$ \\
\hline
\end{tabular}

the RISC-KIT tools, we highlight the lessons-learned and provide a number of recommendations. We reflect on how these findings bear relevance in particular to the Sendai Framework and the EU Floods Directive.

\subsection{From single hazard to multi-hazard impact assessments}

The RISC-KIT project progressed from the previous state-of-the art of analysing single hazards to multiple hazards, and from assessing direct impacts to indirect impacts, systemic disruptions and recovery (Viavattene et al., 2017 this issue). This work leads to an impact-based forecasting approach (Jäger et al., 2017 this issue) in which we can assess where and how these multiple hazards will likely affect social and economic systems and infrastructure in coastal areas. This enables a more intelligent and cost-effective selection of DRR measures and emergency management. The Sendai Framework (UNISDR, 2015) likewise refers to the need to assess and anticipate the potential economic and social impacts of disasters (UNISDR, 2015, section 31 (d)).

\subsection{Promote information and assessment tool development}

RISC-KIT has developed two main types of tools: informative (Storm Impact Database and Web-based Management Guide) and assessment (CRAF, Hotspot Tool, Multi-Criteria Assessment) tools. This generic suite of tools makes a significant contribution to coastal DRR in Europe and beyond, as it answers needs expressed in the Flood Directive implementation (Collaborative Working Group, 2017). It also provides contributions to the Sendai Framework's Priorities \#1 (Understanding Disaster Risk), \#2 (Strengthening disaster risk governance to manage disaster risk) and \#4 (Enhancing disaster preparedness for effective response).

The application of the above tools in 10 different case study sites demonstrated their robustness and wide applicability. Indeed, the CRAF has already been applied beyond the case study areas. This application is both in Europe (the Cadiz coastal area and Denmark) and beyond: the application of the CRAF Phase 1 to identify and rank possible hotspots along the coasts of Ivory Coast, Ghana, Togo and Benin in West Africa (Bolle, pers. Comm.). The further application of such tools on the scale of large coastal areas will permit the identification and ranking of coastal risk hotspots and the optimisation of resources by identifying priorities of action for each coastal hazard. The implementation of such a tool can, thus, provide a clear vision on what are the expected risks and their potential indirect effects at a regional scale, promoting a vision for needs on coastal management for the next decades as well as an optimisation of resources to be spent.

\subsection{Improve data quality and accessibility of economic and social impacts of disasters}

All tool applications have shown a need for spatially-accurate and upto-date topographic, physical, exposure, vulnerability, and post-event impact data using uniform standards. Priority 1 of the Sendai Framework also points to the need to systematically evaluate, record, share, and publicly account for disaster losses and understand the economic, social, health, education, environmental and cultural heritage impacts, as appropriate, in the context of event-specific hazard-exposure and vulnerability information (UNISDR, 2015, section 24 (d)). One of the advances of the RISC-KIT project was the collection of such data in a Coastal Storm Impact Database (Ciavola et al., 2017 this issue).

\subsection{Support more multi-disciplinary collaborations}

The development of the RISC-KIT tool kit was only possible with a project team consisting of engineers, modellers, geographers, economists, historians, anthropologists, environmental and social scientists, all undertaking and applying interdisciplinary research methods and learning outside their comfort zones. This integration of knowledge systems furthermore contributes to the Sendai Framework (UNISDR, 2015, section 24 (h)) which highlights the need to promote and improve dialogue and cooperation among scientific and technological communities.

\subsection{Promote combinations of measures including ecosystem-based solutions}

In some RISC-KIT case study areas, single DRR measures did not provide adequate risk reduction (Barquet et al., 2017 this issue; Plomaritis et al., 2017a this issue). Rather, the combination of more than one DRR measure can be a more effective solution. In particular, the combination of prevention with mitigation measures was positively received in dialogue with RISC-KIT end-users. However, ecosystem-based solutions (EBS) were seldom selected and taken up by the end-users (Barquet and Cumiskey, 2017 this issue). Two main causes for this were identified: 1) a lack of clear evidence that EBS could be as effective as traditional DRR measures; 2) EBS generally require more physical space than traditional structural DRR measures. If these barriers could be overcome, EBS can be more effectively integrated into DRR planning.

\subsection{Stronger stakeholder involvement}

Stakeholders, not only experts but also ordinary citizens, played an important role as providers and recipients of information on coastal risk and approaches to DRR. In the RISC-KIT project, local residents are understood as gatekeepers of important historical and cultural knowledge, who often hold the key to understanding behaviours and attitudes in relation to coastal risk and DRR approaches and measures. The importance of this type of engagement is also reflected in the Sendai Framework guiding principles (UNISDR, 2015, section 19 (d)), which note that effective disaster risk reduction requires an 'all-of-society' engagement and partnership. This is also an important component of the implementation of the Floods Directive (section 9) (European Commission, 2013), which aims for the 'active involvement of all interested parties'.

\subsection{Dissemination: tailor research output to the audience}

RISC-KIT took advantage of online and offline media tools and 
networking to inform the public, stakeholders and end-users about the project and its products. RISC-KIT has paid particular attention to adapt the language and format of the message to each of the target audiences in question. The Sendai Framework recognises the need to disseminate disaster risk information, not only to decision makers but to the general public and communities at risk of exposure to disaster, in an appropriate format (UNISDR, 2015, section 24 (c)) towards empowerment and inclusive, accessible and non-discriminatory participation (UNISDR, 2015, section 19 (d)).

\section{Conclusions}

The RISC-KIT toolkit contains both informative and assessment tools that can provide substantial support to coastal disaster risk reduction. The informative tools (Storm Impact Database and Web-based Management Guide) combine information on physical and environmental features of the coast with information on society, culture, history and governance. These tools demonstrate the relevance of the interdisciplinary and holistic approach to understanding and reducing disaster risk undertaken in the RISC-KIT project and provide practical examples of how this integrative approach can be applied. The Coastal Risk Assessment Framework (CRAF), Hotspot Tool and Multi-criteria Assessment (MCA) constitute a suite of assessment tools which allow areas of coastal risk to be identified, the effectiveness of existing and future DRR measures to be assessed and for these to be ranked and agreed upon with stakeholders.

The application of the CRAF and Hotspot tool at 10 case study sites with different forcing, morphological and exposure/vulnerability conditions reinforces the robustness of the methods and their wide potential of application. They are therefore valuable instruments for coastal management and risk reduction. With regard to the application of the MCA tool, the workshops provided an excellent opportunity for stakeholders to come together; in many cases triggering connections between actors who were previously unknown to one another. The MCA workshops were able to raise awareness of local risk and measures for prevention, protection and mitigation.

The tools thus proved to be effective and broadly applicable but they also need to be further applied and tested to different contexts and environments. The project offers these tools with the sincere hope that they may be used throughout Europe and beyond for effective coastal management.

Many of the details of the tools and their application on a diverse set of case study sites are provided in the set of papers in this issue.

\section{Acknowledgements}

The work described in this publication was supported by the European Community's 7th Framework Programme through the grant to the budget of RISC-KIT, contract no. 603458 , and by contributions by the partner institutes.

\section{References}

Armaroli, C., Duo, E., Validation of the coastal storm risk assessment framework along the Emilia-Romagna coast, Coast. Eng., Available online 1 September 2017, ISSN 03783839, https://doi.org/10.1016/j.coastaleng.2017.08.014.

Baart, F., Bakker, M.A.J., van Dongeren, A., den Heijer, C., van Heteren, S., Smit, M.W.J., van Koningsveld, M., Pool, A., 2011. Using 18th century storm-surge data from the Dutch coast to improve the confidence in flood-risk estimates. Nat. Hazards Earth Syst. Sci. 11 (10), 2791-2801.

Barquet, K., Cumiskey, L., Using participatory Multi-Criteria Assessments for assessing disaster risk reduction measures, Coast. Eng., Available online 17 August 2017, ISSN 0378-3839, https://doi.org/10.1016/j.coastaleng.2017.08.006.

Barquet, K., Dickin, S.K., Meijer, J.J., Dastgheib, A., Testing RISC-KIT's integrated approach for assessing Disaster Risk Reduction measures on the coast of Kristianstad, Sweden, Coast. Eng., Available online 16 August 2017, ISSN 0378-3839, https://doi. org/10.1016/j.coastaleng.2017.08.007.

Baxter, P.J., 1953. A summary of the human disaster 1 February - the east coast Big Flood, 31 January. Philos. Trans. R. Soc. A 363, 1293-1312. https://doi.org/ 10.1098/rsta.2005.1569, 2005
Bertin, X., Bruneau, N., Breilh, J.-F., Fortunato, A.B., Karpytchev, M., 2012. Importance of wave age and resonance in storm surges: the case Xynthia, Bay of Biscay. Ocean. Model. 42, 16-30.

Bogaard, T., De Kleermaeker1, S., Jäger, W.S., van Dongeren, A., 2016. Development of Generic Tools for Coastal Early Warning and Decision Support. Proceedings FLOODrisk 2016-3rd European Conference on Flood Risk Management. https:// doi.org/10.1051/e3sconf/20160718017.

Bolle, A., Das Neves, L., Smets, S., Mollaert, J., Buitrago, S. An Impact-oriented Early Warning and Bayesian-based Decision Support System for flood risks in Zeebrugge Harbour. Coast. Eng., accepted.

Christie, E.K., Spencer, T., Owen, D., McIvor, A.L., Möller, I., Viavattene, C. Regional coastal flood risk assessment for a tidally dominant, natural coastal setting: North Norfolk, southern North Sea, Coast. Eng., Available online 26 June 2017, ISSN 03783839, https://doi.org/10.1016/j.coastaleng.2017.05.003.

Ciavola, P., Harley, M.D., den Heijer, C. The RISC-KIT storm impact database: A new tool in support of DRR, Coast. Eng., Available online 27 September 2017, ISSN 03783839, https://doi.org/10.1016/j.coastaleng.2017.08.016.

Collaborative Working Group, 2017. Flood Risk Management in the EU and the Floods Directive's 1st Cycle of Implementation (2009-15). https://circabc.europa.eu/sd/a 8768cbc2-85f3-428f-b859-f9aee7a27e56/FD\%201st\%20cycle\%20questionnaire\% 20report_formatted_07\%20March\%202017.pdf.

COM, 2014. Technology Readiness Levels (TRL). HORIZON 2020 - WORK PROGRAMME 2014-2015, General Annexes, Extract from Part 19-Commission Decision C(2014) 4995.

Cumiskey, L., Priest, S., Valchev, N., Viavattene, C., Susana Costas, Joseph Clarke, A framework to include the (inter)dependencies of Disaster Risk Reduction measures in coastal risk assessment, Coast. Eng., Available online 31 August 2017, ISSN 03783839, https://doi.org/10.1016/j.coastaleng.2017.08.009.

De Angeli, S., D'Andrea, M., Cazzola, G., Duo, E., Rebora, N. Coastal Risk Assessment Framework: Comparison of modelled fluvial and marine inundation impacts, Bocca di Magra, Ligurian coast, Italy, Coast. Eng., Available online 28 September 2017, ISSN 0378-3839, https://doi.org/10.1016/j.coastaleng.2017.09.011.

De Roo, A.P.J., Wesseling, C.G., Van Deurzen, W.P.A., 2000. Physically based river basin modelling within a GIS: the LISFLOOD model Hydrological Processes, 14 1981-1992.

European Commission, 2013. Guidance for Reporting under the Floods Directive (2007/ 60/EC). Brussels.

Ferreira, O., Viavattene, C., Jimenez, J., Bolle, A., das Neves, L., Plomaritis, T., McCall, R., Van Dongeren, A. Storm-induced risk assessment: evaluation of two tools at the regional and hotspot scale. Coast. Eng., accepted.

Garnier, E., Surville, F., 2010. La tempete Xynthia face à l'histoire. Submersions et tsunamis sur les littoraux français du Moyen Age à nos jours, ISBN 978-2-36199-0091.

Garnier E., Ciavola, P., Spencer, T., Ferreira, O., Armaroli, C., McIvor, A. Historical analysis of storm events: Case studies in France, England, Portugal and Italy, Coast. Eng., Available online 4 July 2017, ISSN 0378-3839, https://doi.org/10.1016/j. coastaleng.2017.06.014.

Gerritsen, H., 2005. What happened in 1953? - the big flood in The Netherlands in retrospect. Philos. Trans. R. Soc. A Math. Phys. Eng. Sci. 363 (1831), 1271-1291. URL. https://doi.org/10.1098/rsta.2005.1568.

Hinkel, J., Lincke, D., Vafeidis, A.T., Perrette, M., Nicholls, R.J., Tol, R.S.J., Marzeion, B., Fettweis, X., Ionescu, C., Levermann, A., 2014. Coastal flood damage and adaptation costs under 21st century sea-level rise. PNAS 2014 (111), 3292-3297.

Huguet, J.-R., Bertin, X., Arnaud, G. Managed realignment to mitigate storm-induced flooding: A case study in La Faute-sur-mer, France, Coast. Eng., Available online 19 August 2017, ISSN 0378-3839, https://doi.org/10.1016/j.coastaleng.2017.08.010.

Jäger, W.S., Christie, E.K., Hanea, A.M., den Heijer, C., Spencer, T. A Bayesian network approach for coastal risk analysis and decision making, Coast. Eng., Available online 3 July 2017, ISSN 0378-3839, https://doi.org/10.1016/j.coastaleng.2017.05.004.

Jäger, W.S., den Heijer, C., Bolle, A., Hanea, A.M., 2015. A Bayesian network approach to coastal storm impact modeling, 12th International Conference on Applications of Statistics and Probability in Civil Engineering (ICASP12). https://doi.org/10.14288/ 1.0076218.

Jiménez, J.A., Sanuy, M., Ballesteros, C., Valdemoro, H.I. The Tordera Delta, a hotspot to storm impacts in the coast northwards of Barcelona (NW Mediterranean), Coast. Eng., Available online 17 August 2017, ISSN 0378-3839, https://doi.org/10.1016/j. coastaleng.2017.08.012.

Kolen, B., Slomp, R., van Balen, W., Terpstra, T., Bottema, M., Nieuwenhuis, S., 2010. Learning from French experiences with storm Xynthia - damages after a flood. Netherlands Ministery of Infrastructure and Environment. ISBN 978-90-77051-77-1. Retrieved from. http://publicaties.minienm.nl/documenten/learning-from-frenchexperiences-with-storm-xynthia-damages-afte.

Lumbroso, D.M., Vinet, F., 2011. A comparison of the causes, effects and aftermaths of the coastal flooding of England in 1953 and France in 2010. Nat. Hazards Earth Syst. Sci. 11 (8), 2321-2333. https://doi.org/10.5194/nhess-11-2321-2011.

Martinez, G, Armaroli, C., Costas, S., Harley, M., Paolisso, M. J. Experiences and results from interdisciplinary collaboration: Utilizing qualitative information to formulate disaster risk reduction measures for coastal regions, Coast. Eng., Available online 17 October 2017, ISSN 0378-3839, https://doi.org/10.1016/j.coastaleng.2017.09.010.

McGranahan, G., Balk, D., Anderson, B., 2007. The rising tide: assessing the risks of climate change and human settlements in low elevation zones. Environ. Urban. 19 (1), 17-37.

Perini, L., Calabrese, L., Lorito, S. and Luciani, P. (2015) Coastal flood risk in EmiliaRomagna (Italy): the sea storm of February 2015, in: Coast. Marit. Mediterr. Conf. Ed. 3, FERRARA, ITALY, 2015: pp. 225-230. http:dx.doi.org/10.5150/cmcm.2015.044. 
Plomaritis, T.A., Costas, S., Ferreira, Ó. Use of a Bayesian Network for coastal hazards, impact and disaster risk reduction assessment at a coastal barrier (Ria Formosa, Portugal), Coast. Eng., Available online 26 July 2017 a, ISSN 0378-3839, https://doi. org/10.1016/j.coastaleng.2017.07.003.

Plomaritis, T.A., Ferreira, Ó., Costas, S. Regional assessment of storm related overwash and breaching hazards on coastal barriers, Coast. Eng., Available online 28 September 2017b, ISSN 0378-3839, https://doi.org/10.1016/j.coastaleng.2017.09. 003.

Poelhekke, L., Jäger, W.S., Plomaritis, T.A., Van Dongeren, A.R., McCall, R.T., Ferreira, O., December 2016. Predicting coastal hazards for sandy coasts with a Bayesian Network. Coast. Eng. 118, 21-34. ISSN 0378-3839. https://doi.org/10. 1016/j.coastaleng.2016.08.011.

Roelvink, J.A., Reniers, A., Van Dongeren, A., Van Thiel de Vries, J., McCall, R., Lescinski, J., 2009. Modeling storm impacts on beaches, dunes and barrier islands. Coast. Eng. https://doi.org/10.1016/j.coastaleng.2009.08.006.

Roelvink, J.A., McCall, R.T., Mehvar, S., Nederhoff, C., Dastgheib, A. Improving predictions of swash dynamics in XBeach: The role of groupiness and incident-band runup, Coast. Eng., Available online 21 July 2017, ISSN 0378-3839, https://doi.org/ 10.1016/j.coastaleng.2017.07.004

Stelljes, N., Martinez, G., McGlade, K. Introduction to the RISC-KIT web based management guide for DRR in European coastal zones, Coast. Eng., Available online
27 September 2017, ISSN 0378-3839, https://doi.org/10.1016/j.coastaleng.2017.09. 012.

UNISDR, 2015. http://www.unisdr.org/files/43291_sendaiframeworkfordrren.pdf.

Valchev, N., Eftimova, P., Andreeva, N. Implementation and validation of a multi-domain coastal hazard forecasting system in an open bay, Coast. Eng., Available online 23 August 2017, ISSN 0378-3839, https://doi.org/10.1016/j.coastaleng.2017.08.008.

Van Dongeren, A., Ciavola, P., Viavattene, C., De Kleermaeker, S., Martinez, G., Ferreira, O., Costa, C., McCall, R., 2014. RISC-KIT: resilience-increasing strategies for coasts - toolKIT. J. Coast. Res. Special Issue 70-Proceedings 13th Int. Coast. Symposium 366-371. https://doi.org/10.2112/SI70-062.1.

Viavattene, C., Jimenez, J., Ferreira, O., Priest, S., Owen, D., McCall, R. Selecting coastal hotspots to storm impacts at the regional scale: the Coastal Risk Assessment Framework, Coast. Eng., Available online 22 September 2017, ISSN 0378-3839, https://doi.org/10.1016/j.coastaleng.2017.09.002.

Werner, M., Schellekens, J., Gijsbers, P., van Dijk, M., van den Akker, O., Heynert, K. The Delft-FEWS flow forecasting system, In Environmental Modelling \& Software, Volume 40, 2013, Pages 65-77, ISSN 1364-8152, https://doi.org/10.1016/j.envsoft. 2012.07.010.

WSB - Wasserstraßen und Schifffahrtsverwaltung des Bundes, 2015. Extreme Hochwasserstände $[\mathrm{cm}]$ der Ostsee Werte $\geq 650 \mathrm{~cm}$ bzgl. PNP. Retrieved 12.09.2016, from. http://www.wsaluebeck.wsv.de/wasserstrassen/ gewaesserkunde/historisch/pdf/Hochwasserstaende.pdf. 